\title{
Interpersonal communication within Romanian medical field
}

\section{DOI: http://doi.org/10.26758/8.1.1}

Valentina Marinescu (1), Ioana Silistraru (1)

Faculty of Sociology and Social Work, Bucharest, Romania

Address correspondence to: Valentina Marinescu, Faculty of Sociology and Social Work, Bd. Schitu Măgureanu, No. 9 - Bucharest, Romania. Ph.: +40720024813; E-mail: vmarinescu9@ yahoo.com

\begin{abstract}
Objectives. At present, it is widely recognized that improving quality in healthcare delivery had become an extremely important topic for research. The objective of this study is to compare the types of interpersonal communication between Romanian patients and their general practitioners (GPs) with the discussions between Romanian pharmacists and the patients.

Material and methods. A quantitative method based on a comparative design for analyzing a sample of 199 respondents was conducted. The questionnaire consists of ten open questions plus five socio-demographic items. Descriptive statistics was used in the analysis of the result.

Results. A high percentage of the respondents (35\%) did assess pharmacists as simple dealers and most of them did not communicate with the pharmacists during their encounters. At the same time, only $15 \%$ of the entire sample had discussed more than a half an hour with their GPs, the main subjects of discussions being rather "standardized" (i.e. current treatments and the general health).

Conclusions. Lack of trust in the medical system and medical staff is directly linked not only to the economic and logistic conditions (lack of proper financing, massive migration of doctors, etc.) but it is also a consequence of the "improper" interpersonal communication between the patients and the Romanian medical staff. The basic conclusion of the study is that new strategies and plans for improving interpersonal communication among patients, GPs and pharmacists are needed at present in Romania.
\end{abstract}

Keywords: interpersonal communication; patients; doctors; pharmacists.

\section{Introduction}

Communication between patient and physician is analyzed in order to extract a series of information that will improve the overall medical act designed to heal or alleviate the suffering of the first (i.e. the patient). Doctor-patient bi-directional communication is at the basis of some modern concepts in medical care - patient-centered care or shared decision-making, both designed to significantly improve the quality of the medical act and to limit diagnostic errors and treatment (Stewart, 2005).

\section{Medical narrative - medicine practiced with communication skills}

With the development of the medical narrative study, a new discipline emerged. This is a discipline that analyses the narratives identified during the physician-patient dialogue, especially for decrypting the narrative exposed by the patient, so that the purpose of the medical act is to cure or alleviate suffering. Kathryn Montgomery Hunter (1991) defined medical narrative as an art that 
depends crucially on the ability to say and interpret a story - the story of the patient's illness and suffering.

The medical narrative supports the physician and the patient as the most complex instrument of medicine casuistic that allows practitioners to share diagnosis and vision of the therapeutic act, to circumscribe a single case and, at the same time, to obtain sufficient generalizations which would be useful both in practice and in the improvement of their profession.

The dialogue is at the heart of the medical act due to the fact that medicine is fundamentally narrative, according to Hunter (1991). This is especially true for evidence-based medicine that is usually practiced in university hospitals, and the most important narratives the physician must take into account are those occurring just at the beginning of the interaction with their patient.

Patient narrative recorded inside the medical office or hospital where he or she meets the physician is very different from the vivid color descriptions, the true "war stories" that the patient reports outside of the medical setting. At the first meeting with the doctor, there is the autobiographical narrative that describes a "chronicle" of suffering from a personal perspective, with elements organized sometimes chronologically, with descriptions made in her or his own language of how the disease affects her or him. This is essentially the first narrative that the practitioner receives, and in terms of narrative medicine, it might be one of the most important for the subsequent evolution of his or her relationship with the patient. The structure of the medical narrative is supplemented by the narrative of the doctor or the therapist. He or she (i.e. the practitioner) will use his or her own language and usually will intervene in the patient's narrative to order the useful information for a potential diagnosis in an anamnesis. Hunter $(1991, \mathrm{p} .8)$ uses the concept of "patient as text", which can be understood according to the narrator's skills. The medical profession involves not only a cognitive engagement, as each interaction with the patient brings new information, but also emotional engagement, when the doctor empathizes with his or her suffering. The two levels, cognitive and emotional, are the basis of an intuitive, creative, doctor-specific mechanism that puts together all the information within the interaction with the patient (Stewart, 2005, p.793).

The narrative approach takes into account the patient's narrative and interpretation of the disease. People live in realities they have been symbolically built (Pendelton and Hasler, 1983, p.34) and the symbols used in the disease's narrative are the meanings that the experience of the disease brought to the patients. The only way to decrypt those meanings, writes Pendelton and Hasler (1983), is to examine the narrative of the disease, namely the narrative of the patient.

\section{Patient's expectations of the relationship with his doctor}

According to Stewart (2005), there are two elements needed for the success of doctorpatient communication: the doctor's openness to listen to the patient's story and his or her willingness to learn something new with each narrative run by each patient.

"I have witnessed magical moments during patient meetings with their doctors; I have witnessed the mystery of medical practice and have seen the evolution of patients from sickness to health and vice versa. I have seen many times the way doctors help patients to rebuild their lives for all their lives" (Stewart, 2005, p.793).

The dialogue between physician and patient is the key component of the healthcare system, especially in basic medical care (Beck, Daughtridge and Sloane, 2002, p.25) On the other hand, according to Lipkin, Putnam, and Lazare (1995), it is estimated that a general practitioner performs between 120,000 and 160,000 interviews during a 40-year career. In terms of the quality of physician-patient communication, according to Beck, Daughtridge and Sloane (2002), this has often 
been considered inappropriate. Most patients who were interviewed by Beck, Daughtridge and Sloane assessed that communication skills are among the top three abilities a physician must have, but they have frequently complained that their doctors have less satisfactory communication expertise (Beck, Daughtridge and Sloane, 2002, p.25).

\section{The informed patient}

Medical information is increasingly available from other alternative sources than the medical staff. Since the early 1970's, studies and researches on medical communications have highlighted this quality of the patient, that is, his or her need to be informed and able to ask information specific to him or her (Waitzkin and Stoeckle, 1972). Keating, McDermott, and Montgomery (2014) have shown that there are benefits in the therapeutic process for the patient if he or she is informed and educated and this perspective has become dominant in the research centered on generally improving medical performance. The same researchers are mentioning physician-patient communication as a key element in achieving the goals of the medical act. In this case, physician-patient communication has to involve the assimilation of medical vocabulary and to enable the patient to assign real symptomatology, which becomes a source of relevant information for later diagnosis (Keating, McDermott and Montgomery, 2014, p.14).

\section{Consultation - dialogue between physician and patient}

The definition of consultation, equating with physician-patient dialogue, is that of a "meeting" between two people who usually try to influence one another (Pendelton and Hasler, 1983). Each of them has its own beliefs and ideas, its own feelings and motives, values and needs brought within the consultation. According to Pendelton and Hasler (1983), the key is "mutual understanding". "Understanding", as it is used in "New Consultation - Developing Doctor-Patient Communication", is the result of a process that involves formal learning and information, general and professional socialization, as well as individual experience and education.

"(Consciousness - AN) is a mixture of cognition and affection: the thoughts and feelings that govern the physician's and patient's guidance and which contribute to the modeling of its content" (Pendelton and Hasler, 1983, p.20).

\section{Clinician pharmacist's role in patient compliance with treatment}

The existing literature (Francis and Abraham, 2014, p.600) provides a special role for the clinician in securing that the patient complies with the recommended treatment of the physician. The clinical pharmacist is the specialist who interacts most with the patient to guide, to get medical and therapeutic history, to check for medication errors (including prescribing and administration), to identify possible interactions between prescription drugs, to suggest a personalized dosage and to counsel the patient (Francis and Abraham, 2014, p.600).

In the Romanian medical system, the pharmacist is a relatively new category, and, as such, he or she is little understood, on the one hand. On the other hand, the existing literature and the specialists themselves recognize that the ideal collaboration relationship between the clinician and the patient must be close and in the benefit of the patient (***Pagina Farmaciștilor, 2017).

The clinician should be present at all pharmacies in the community, and any patient may be able to address the side effects he or she may have, ask him or her when and how to contact the doctor if needed. The relationship between the clinician and the patient should be a close one, but for this, the patient must be educated that this specialization exists and that it is something different in the occupational spectrum (***Săptămâna Medicală, 2017). 


\section{Methodology}

In order to study patient-physician and patient-pharmacist communications, an exploratory research project has been made. A quantitative method based on a comparative design for analyzing a sample of 199 respondents has been used. The data were collected in November 2016-March 2017 with the help of an anonymous online questionnaire applied in Bucharest. The questionnaire consisted of ten open questions plus five socio-demographic items.

The method of analyzing the data was an iterative one: the observational codes in the answers have been first identified, then all responses were coded with axial codes, and were transferred to an Excel file. The resulting file was further transformed into an SPSS file, which was analyzed using this statistical package.

\section{Case presentation}

When asked how they can characterize the health system in Romania a huge percentage $(83.4 \%)$ of the respondents used negative statements.

Table 1. How can you characterize the situation of the health system in Romania?

\begin{tabular}{|l|c|}
\hline & $\%$ \\
\hline Positive & 5.5 \\
\hline Middle situation & 7.5 \\
\hline Negative & 83.4 \\
\hline
\end{tabular}

The main arguments used in negative assessments of the Romanian medical system enclosed references to "poverty" (e.g. lack of financial resources and logistic shortages), "corruption", bad management, bureaucracy and lack of understanding from the part of medical staff toward patients' needs. Some examples are below:

"It is poverty in the system. And that is because resources are not well managed, partly due to corruption, partly due to the poor involvement of the Government in the system, and a high degree of bureaucracy. As a result, we have a medical system that does not focus on prevention and where everyone manages on his/her own, either going to the private clinics or avoiding accessing medical services."

"It is a disaster. The medical system is broken primarily due to the attitude of the medical staff, which believed of themselves to be a kind of semi-gods. Secondly, it is due to the attitude of servants that patients have. And, in third place, I should point out the managers of the system who are, in fact, the big thieves who take bribes without worrying to destroy a system, which is already crumbling."

"It is a precarious situation. There is no good communication in the system. What should make ease the lives of doctors and patients in fact put a burden on them. And I refer here at the bureaucracy, at the health cards that do not work, and the payments that are not done in time for the suppliers of different services...".

"There is no concern for the patient's well-being and for the creation of a well-functioning system in which both those who work within it and those who benefit from it to be satisfied. I must add that, 
generally, good health systems are not cheap."

As the data show, in $40.4 \%$ of the cases, the General Practitioners were negatively assessed by the respondents. The situation was mainly due to the direct contact the interviewees had with the doctors. "Lack of empathy", "superficial", "not interested in patients' situation" were only a few characteristics laying at the basis of negative evaluations of GPs relations with respondents, as shown below:

He seems to be nonhuman ... unfortunately! The GP or family medicine should be the most important point for primary prevention.

Oh,...he is superficial. And that's just because he is prescribing my antibiotic on the phone, if you can imagine that.

He is non-existent. He is no longer professing and informs me that he has "passed this dance" to his wife. I never met her. I even wonder if I can be enlisted to another GP without removing the file from where she is now.

He is not serious; his secretary prints you the receipt.

A person who is not at all interested in the patient's situation and offers very strong treatments regardless of the patient's illnesses and symptoms.

At the same time, $35.1 \%$ of the sample equated the pharmacists with shop assistants, as shown in the citations from below:

She is a sales employee who does not know medicine more than me.

He is always in a hurry. He is giving quickly a medicine without listening to all you have to say. And he is insistent with selling non-generic drugs.

He is very helpful! It has never happened to me to enter the pharmacy and not be listened.

I met pharmacists very well trained. Near the block where I live there is a pharmacy with a lab and I often buy products prepared by the pharmacists working there. They're more effective.

Oh, she is a simple seller (I do not trust her advice).

Concerning the last visit to the GPs, $21.3 \%$ of the respondents declared that it was two or three months before, while for $22.8 \%$ of them the visit was made six months before. At the same time, the contacts with the pharmacists were in a shorter time-span: over a half of the respondents $(66 \%)$ declared that they went to a pharmacy the same month and around one-third (23.4\%) a month before. 
Table 2. When did you visit the last time your personal GP and when did you go for the last time to a pharmacy?

\begin{tabular}{|l|c|c|}
\hline & Last visit at the personal GP (\%) & Last visit at the pharmacy (\%) \\
\hline This month & 11.6 & 66 \\
\hline Last month & 16.1 & 23.4 \\
\hline Two or three months ago & 21.1 & 8.1 \\
\hline Six months ago & 22.6 & 2 \\
\hline Last year & 10.6 & - \\
\hline More than a year ago & 18.1 & 0.5 \\
\hline
\end{tabular}

The reasons for visiting the GPs were: to obtain a medical certificate for a specialist doctor $(23.7 \%)$, to make a medical control $(34 \%)$, to obtain a general medical certificate $(12.9 \%)$, and to make the personal set of medical analysis (12.4\%).

In general, the respondents acknowledged that their visit to the GPs lasted between one to twenty minutes (59.4\%) and only $17.8 \%$ declared that their last visit lasted between 20 and 30 minutes.

The main topics of discussion with the GP's were "general personal health status" $(26.2 \%)$, "disease symptoms" (15.4\%), "treatment" (12.8\%) and "interpretation of the analysis and diagnostic" (11.8\%). While only $11.8 \%$ of the respondents did not have any discussion with their GPs, almost one-third of them $(29.2 \%)$ declared that they did not communicate with the pharmacists when they went to the pharmacy.

Table 3. Topic of discussion with GPs vs. topic of discussion with pharmacists

\begin{tabular}{|l|c|l|c|}
\hline \multicolumn{1}{|c|}{ Topic of discussion with GPs } & $\%$ & Topic of discussion with pharmacists & $\%$ \\
\hline Disease symptoms & 15.4 & Modes of drug administration & 10.8 \\
\hline General health status & 26.2 & $\begin{array}{l}\text { Recommendations for other drugs than } \\
\text { those prescribed by the doctor }\end{array}$ & 23.8 \\
\hline About the treatment & 12.8 & The price of drugs & 7 \\
\hline Prevention & 6.2 & $\begin{array}{l}\text { Explanation regarding the recipes and } \\
\text { drugs }\end{array}$ & 7.6 \\
\hline $\begin{array}{l}\text { Interpreting the analysis and } \\
\text { diagnosis }\end{array}$ & 11.8 & General topics relating to medicine & 17.3 \\
\hline I have no discussion & 11.8 & I have no discussion & 29.2 \\
\hline Another situation & 15.9 & Another situation & 4.3 \\
\hline
\end{tabular}

Almost a quarter of the total number of respondents $(23.8 \%)$ had communicated with the pharmacists to obtain recommendations for other drugs than those prescribed by their doctors and $17.3 \%$ had a discussion on general topics related to medicine.

When asked about the degree of trust in different occupations within the medical field, the respondents showed that surgeons, specialist doctors, and dentists were credited with relatively high levels of public trust (between 29.6\% for surgeons and $26.1 \%$ for dentists). 
Table 4. What is your degree of trust in ... (\%)

\begin{tabular}{|l|c|c|}
\hline & The lowest (rank 1) & The highest (rank 5) \\
\hline GP & 16.1 & 19.1 \\
\hline Medical assistant & 9.5 & 6.5 \\
\hline Dentist & 3.5 & 26.1 \\
\hline Pharmacist & 12.6 & 9 \\
\hline Specialist doctor & 1.5 & 28.6 \\
\hline Surgeon & 2.5 & 29.6 \\
\hline
\end{tabular}

The results showed that pharmacists and medical assistants had the lowest level of trust among the respondents, with $9 \%$ of the interviewees/respondents highly ranking the pharmacists and only $6.5 \%$ declaring a high trust in medical assistants. With $19.1 \%$ of the total sample assessing a high degree of trust in them, the GPs were placed in the middle position within the respondents' evaluations.

\section{Discussions and conclusions}

Officially, in Romania, primary care, provided through the General Practitioners (Family Doctors), represents the first contact of the population with the health system, both for the diagnosis and treatment of the diseases, as well as for carrying out preventive medical examinations. In 2016, most Romanian GP offices operated in urban areas, 6.7 thousand compared to 4.6 thousand in rural areas, where a family doctor's office has to take care of 1.3 times more inhabitants (belonging to the resident population in the village) compared to an urban one (***Institutul Naţional de Statistică, 2017). Out of the total number of Romanian doctors, $21.5 \%$ were GPs, nearly two-thirds of them practicing in the urban area (***Institutul Național de Statistică, 2017).

In 2016, the discrepancies regarding the access to the medical staff per residential areas are evident. More exactly, in the rural area, 7.9 times more inhabitants do not have access to a doctor as compared with those from the urban areas. Also, in rural areas, 6.1 more times inhabitants do not have access to a dentist as compared with those from the urban areas. Finally, compared with inhabitants from urban areas, 4.0 more times inhabitants from rural areas do not have access to a pharmacist (***Institutul Naţional de Statistică, 2017).

In Bucharest, in May 2016 there were around 977 General Practitioners who had a direct work contract with Bucharest Health Insurance House (***Casa de Asigurări de Sănătate a Municipiului București, 2017). As the statistical data show, in 2015, in Bucharest, for every 100.000 inhabitants, there have been 654 doctors, 90.7 General Practitioners and 563.3 specialist doctors (***Fundaţia Comunitară București, 2017).

Despite the fact that Bucharest is in a better position than the rest of the country as regards the ratio of medical staff to the number of inhabitants our data reveal that there is a general lack of confidence in the health system a whole, doctors, and pharmacists. The reasons behind this situation comprise not only financial problems, management shortages or out-dated technologies, but also the lack of communication with medical personnel.

The fact that GPs have become a sort of state-bureaucrats (according to our respondents they only write prescriptions or interpret the set of medical analysis) raises serious problems related to their role in the Romanian medical system, as our respondents have also noticed. More than a half 
of the sample declared that they had discussed no more than twenty minutes with their GPs and only for $6.2 \%$ the topic of conversation was prevention for health-related issues.

The higher frequency of visits to the pharmacy seems to confirm the existing data on the high percentage of Romanians practicing self-medication (***Asociaţia Medicilor de Familie Mureș, 2016). At the same time, the standard image of the pharmacist as a simple shop assistant makes this problem (e.g. self-medication) difficult to control.

Although this is only an exploratory study one can conclude that the lack of trust in Romanian medical system and medical staff is directly linked to the economic and logistic conditions (lack of proper financing, massive migration of doctors, etc.) and is also a consequence of the "improper" interpersonal communication between the patients and the Romanian medical staff (GPs and pharmacists).

We advocate, as such, that some changes have to be done at different. In our opinion, those new strategies and plans for improving interpersonal communication among patients, GPs and pharmacists have to be based on the active involvement of the three parts in the medical act.

Conflict of interest. The authors of this article do not have any conflict of interests.

\section{Bibliography}

1. Beasley, J.W., Starfield, B., van Weel, C., Rosser, W.W., Haq, C.L., 2007. Global health and primary care research. The Journal of the American Board of Family Medicine, 20(6), pp.518526.

2. Beck, R.S., Daughtridge, R., Sloane, P.D., 2002. Physician-patient communication in the primary care office: a systematic review. The Journal of the American Board of Family Practice, 15(1), pp.25-38.

3. Francis, J., Abraham, S., 2014. Clinical pharmacists: Bridging the gap between patients and physicians. Saudi Pharmaceutical Journal, 22(6), pp.600-602.

4. Hunter, K.M., 1991. Doctors' stories: The narrative structure of medical knowledge. New Jersey: Princeton University Press.

5. Keating, M., McDermott, A., Montgomery, K., 2014. Patient-centred health care: achieving coordination, communication and innovation. Houndsmills, Basingstoke: Palgrave Macmillan.

6. Lipkin, M., Putnam, S.M., Lazare, A., 1995. The medical interview. The medical interview: clinical care, education, and research. New York: Springer-Verlag.

7. Pendelton, D.A. (author), and Hasler, J.D. (editor), 1983. Doctor-patient communication. Theory and Practice. London; New York; Sydney: Academic Press.

8. Waitzkin H., Stoeckle, J.D., 1972. The Communication of Information About Illness: Clinical, Sociological, and Methodological Considerations. Advances in Psychosomatic Medicine, 8, pp. $180-215$.

9. ***Asociația Medicilor de Familie Mureș, 2016. Automedicația este un fenomen îngrijorător, 3 din 4 români se tratează fără a consulta medicul de familie, [online] Available at: http://amfms.ro/automedicatia-este-un-fenomen-ingrijorator-3-din-4-romani-se-trateaza-fara-aconsulta-medicul-de-familie/ [Accessed 19 July 2017]

10. ***Casa de Asigurări de Sănătate a Municipiului București, 2017. Deconturi lunare MF, [online] Available at: http://www.cnas.ro/casmb/page/deconturi-lunare-cabinete-mf.html [Accessed 29 July 2017].

11. ***Fundația Comunitară București, 2017. Raportul Vital Signs 2017 București, [online] Available at: http://bucuresti.vitalsigns.ro/sanatate/ [Accessed 28 July 2017]. 
12. ***Institutul Naţional de Statistică, 2017. Comunicat de presă - Domeniul: Statisticasănătăţii 16/30 iunie 2017, [online] Available at: http://www.insse.ro/cms/ro/comunicate-de-presa-view [Accessed 29 July 2017].

13. ***Pagina Farmaciștilor, 2017.Confuzie intre farmacistul generalist de spital si farmacistul clinician, [online] Available at: http://www.paginafarmacistilor.ro/stiri-pharma/confuziefarmacistul-generalist-spital-clinician_5783/ [Accessed 19 July 2017].

14. ***Săptâmăna Medicală, 2017. Necesitatea existenței farmacistului clinician și importanța educației pacientului, printre temele de actualitate dezbătute la FarmaPracticed. 50, [online] Available at: http://www.saptamanamedicala.ro/articole/Necesitatea-existentei-farmacistuluiclinician-si-importanta-educatiei-pacientului-printre-temele-de-actualitate-dezbatute-la-FarmaPractic-ed-50.html [Accessed 18 July 2017]. 